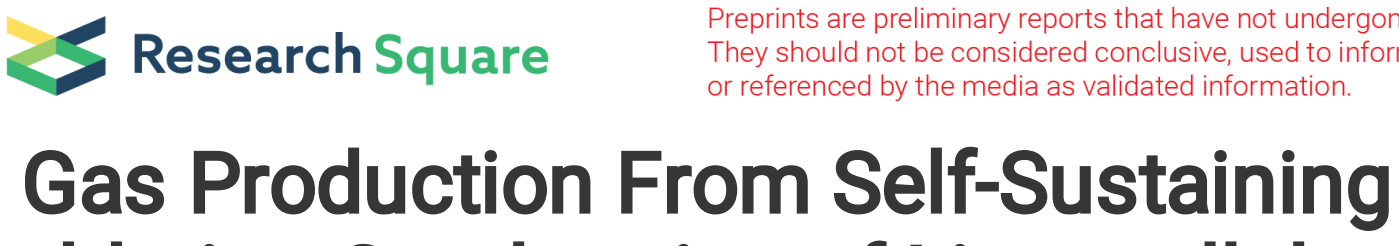 \\ Fuel Gas Production From Self-Sustaining
Smouldering Combustion of Lignocellulosic Waste
}

Hons K Wyn ( $\square$ wyn_hons@hotmail.com )

University of Queensland https://orcid.org/0000-0001-5405-0984

\section{Muxina Konarova}

The University of Queensland Australian Institute for Bioengineering and Nanotechnology

https://orcid.org/0000-0003-1308-420X

\section{Greg Perkins}

The University of Queensland https://orcid.org/0000-0002-3157-1792

\section{Luis Yermán}

The University of Queensland https://orcid.org/0000-0002-1096-9291

\section{Research Article}

Keywords: smouldering combustion, gasification, oxidative pyrolysis, waste treatment, syngas

Posted Date: September 2nd, 2021

DOl: https://doi.org/10.21203/rs.3.rs-817595/v1

License: (c) (1) This work is licensed under a Creative Commons Attribution 4.0 International License.

Read Full License 


\section{Abstract}

Smouldering combustion has shown to be an effective application for soil remediation and as a waste treatment method for solids with high moisture content. The experimental set-up of smouldering combustion reactors is similar to autothermal fixed-bed gasification, updraft reactor configuration. In this study, smouldering experiments were conducted using lignocellulosic agricultural waste. The moisture content of lignocellulosic biomass was varied between $10 \%$ to $50 \%$. Air flux was varied between 1.8 and $7.4 \mathrm{~cm} / \mathrm{s}$. Experiments were also conducted with varying oxygen concentration in the airflow (3.6-21\%), addition of sand (4 and $8 \mathrm{~g} / \mathrm{g}$ ) and other lignocellulosic material (wood pellets, and residual berry plant). Fuel gas with maximum $\mathrm{H}_{2}, \mathrm{CO}, \mathrm{CH}_{4}, \mathrm{CO}_{2}$ concentrations of $7.7,32.6,2.3$, and $57.4 \%\left(\mathrm{~N}_{2}\right.$ free) respectively were obtained with $10 \%$ moisture content and $7.4 \mathrm{~cm} / \mathrm{s}$ air flux. The smouldering yielded $1.24 \mathrm{Nm}^{3} / \mathrm{kg}_{\text {feed_dry }}$ of gas with calorific value of $1.82 \mathrm{MJ} / \mathrm{Nm}^{3}(\mathrm{HHV})$.

\section{Statement Of Novelty}

Research in smouldering combustion has historically been on the topic of fire safety hazard. It has more recently been applied to treatment of soil and destruction of wastes with high moisture content. Since self-sustaining smouldering involves the thermochemical destruction of wastes in low oxygen atmosphere, this provides potential for the production of value-added products alongside the waste treatment of wastes. Research has been conducted on the potential production of liquid, and solid products from self-sustaining smouldering. This research takes the next step and assess the potential for the production of gas products. This research helps contribute to a sustainable future where potential valuable by-products from wastes can be obtained which reduces our reliance on fossil fuels.

\section{Introduction}

\subsection{Smouldering combustion}

Smouldering is a flameless form of combustion characterized by slow-burning rates and temperatures compared to flaming combustion [1]. One of the fundamental differences with flaming combustion is that the oxidation reactions take place on the surface of a solid, rather than in the gas phase, hence, the absence of flames [2]. Smouldering requires a material to be porous to allow air/oxygen to reach the smouldering front, and smouldering gases to flow through the material. An example would be the smouldering tip on a burning cigar. During smouldering combustion, the heat produced from exothermic oxidation reactions is transferred to the surrounding porous material, which is then preheated and ignited, releasing more heat [3]. This cycle allows smouldering to propagate in a self-sustaining manner until heat losses overcome the heat released and the smouldering reaction quenches.

The rate at which oxygen, or air, approaches the smouldering front (i.e. oxidation reaction) is one of the key parameters that control smouldering propagation through the material [1], [4], [5]. For this reason, a separation between natural and forced smouldering is made [4]. Natural smouldering occurs when airflow 
is transported to the smouldering front naturally via buoyancy caused by rising hot gases produced from smouldering. This is the case when smouldering occurs due to a natural occurring fire, such as underground fires [6], or smouldering of peatlands [4]. Forced smouldering occurs when smouldering is utilised for a productive application, in which case, airflow is typically provided using a blower or compressed air [7]. In addition to this classification, depending on the direction of the smouldering front in relation to the flow of air, smouldering operates in two different modes: forward and opposed [8]. Forward smouldering occurs when the smouldering front and airflow travel in the same direction, while opposed smouldering (or reverse combustion) occurs when the smouldering front and airflow travel in the opposite direction.

Smouldering combustion has been historically investigated from a fire safety point of view [1], [9], [10]. More recently, research advanced onto the application of self-sustaining smouldering (SSS) to soil remediation [3], [11]-[15] with commercial utilization [16], [17], and also as waste treatment method using smouldering reactors in a forced-upward-forward configuration [5]. The latter is the focus of the present work. Smouldering applications to waste treatment usually involve the forced-forward smouldering configuration. In this configuration, an external heater heats the base of the column of material and air is injected from below as the smouldering front moves upwards (Fig. 1). This configuration allows the recovery of the majority of the energy released during the exothermic oxidative reactions and therefore, the process can be self-sustaining even at very high moisture contents (75-80 \%) [5], [18].

Smouldering velocity, temperature and gas products are affected by different key parameters that include characteristics of the biomass, such as moisture content, air permeability, dilution with inert material (e.g., sand) and oxidizer such as airflow rate and oxygen concentration.

\subsection{Gas production from smouldering processes}

During smouldering, a myriad of chemical reactions occurs. The type of reactions is dependent on oxygen concentration and temperature, which varies along the height of the reactor with respect to the position of the smouldering front. For example, oxidation reactions take place in the smouldering front, where temperature and oxygen concentration are relatively high. Above the smouldering front, oxygen concentration decreased which promotes pyrolysis reactions and decreases temperature. In this way, the gradient of temperature and oxygen concentration that is created could be used to promote a certain type of reaction (see Figure 2). The separation between the zones represented on Figure 2 are indicative to explain the main type of reactions that take place inside the reactor. A more detailed explanation of the different zones, as well as chemical reactions occurring in the reactor, is available in a review by Wyn et al. [19].

The existence of the pyrolysis zone presents the potential for the production of value-added products, such as biochar [21] and bio-oil [22], [23]. While the production of liquid fuels has been investigated, the conditions required to maximize these products (short residence time and fast heating rates [24]) cannot be attained during SSS. Regarding gas products, thermal degradation of biomass produces pyrolysis 
gases that can react within the oxidative conditions inside the reactor (i.e., gasification) to produce fuel gases. Oxygen concentration and flow rate are critical as they directly affect the temperature in the reaction zone and the oxidation reactions that provide the energy necessary for the various endothermic reactions [5], [18]. Gas products and emission from processes involving smouldering combustion are affected by many products. These are summarised here and are reviewed in detail in [19].

A comprehensive review of the production of valuable gases from smouldering processes can be found in [19]. That review showed that, while more systematic approaches are required, smouldering gas products can be partially controlled with operative conditions such as air flux, moisture content, and some feed characteristics. The majority of the works reviewed there are gasification processes carried out in forward or opposed upward smouldering.

In gasification, the air-to-fuel equivalence ratio (ER) is used to describe the amount of oxygen present in the medium [24]-[26]. The ER is defined as the ratio between the actual air-to-fuel ratio in the reactor and the air-to-fuel ratio required for stoichiometric combustion, where fuel is the solid undergoing smouldering. At an ER of one, the reactions achieve stoichiometric combustion. An ER of above one describes an oxygen-rich atmosphere typical of reactors in incineration plants. An ER value of between zero and one describes combustion with oxygen-limited atmospheres, such as in gasification reactors, or conditions typically attained by smouldering combustion. An atmosphere with an ER of zero does not contain any oxygen and therefore describes pyrolysis. Even though ER does not have the same physical meaning in a smouldering reactor configuration as the one shown in Figure 1 (as ER typically describes continuous processes), this can be estimated and potentially changed to maximize the gas products with fuel characteristics.

This paper investigates the effect of five different parameters on the gas composition of product gases from self-sustaining smouldering combustion of lignocellulosic biomass. A series of smouldering experiments were conducted to test the effects of the solid moisture content, the dilution of the solid with inert sand, the air flux, the oxygen concentration, and the nature of the solid undergoing smouldering combustion. These were conducted in an attempt to change the ER of the atmosphere in the reactor, and therefore the gas composition.

\section{Materials And Methods}

\subsection{Raw materials}

The materials used in this work are used coco coir (UCC), residual berry plant (RBP), and wood pellets (WP). UCC was used in a southeast Queensland (Australia) berry farm as hydroponic substrates for raspberry and strawberry plants. Residual berry plant is the leftover raspberry plant once the berries were harvested and the plant pruned. The wood pellets were provided by Pellet Heaters Australia ${ }^{\odot}$. Results from the proximate and ultimate analyses for the raw materials are presented in Table 1. 
Proximate analysis was conducted following ASTM E1131-08 [27]. The high heating value (HHV) was measured using a Parr 1341 bomb calorimeter equipped with a Parr 6772 calorimetric thermometer. Bulk density was calculated following ASTM E873-82 [28]. The ultimate analysis was carried out using a LECO TruSpec analyser, and the oxygen content was calculated by difference. Simultaneous Thermogravimetric Analysis (TGA) and Differential Scanning Calorimetry (DSC) was conducted on the raw material to investigate its thermal behaviour using equipment from Perkin Elmer, STA6000 model. TGA experiments were conducted under both air and nitrogen at $20^{\circ} \mathrm{C} / \mathrm{min}$ and $20 \mathrm{~mL} / \mathrm{min}$ gas flow.

Table 1. Results from proximate and ultimate analysis of the materials used in the smouldering combustion experiments. $\mathrm{db}=$ dry basis, $\mathrm{wb}=$ wet basis. ${ }^{\mathrm{a}}$ Calculated by difference: $0 \%=100-(\mathrm{C}+\mathrm{H}+$ $\mathrm{N}+\mathrm{S}) \%$.

\begin{tabular}{lllll} 
& Units & UCC & RBP & WP \\
\hline Moisture content & wt \% (wb) & $30-50$ & $28-50$ & $8-12$ \\
\hline Volatile matter & wt \% (db) & $63.5 \pm 1.4$ & $66.9 \pm 0.5$ & $75.5 \pm 0.5$ \\
\hline Fixed carbon & wt \% (db) & $26.9 \pm 0.5$ & $21.3 \pm 0.2$ & $16.2 \pm 0.2$ \\
\hline Ash content & wt \% (db) & $9.6 \pm 1.7$ & $11.9 \pm 0.6$ & $3.7 \pm 0.1$ \\
\hline Higher Heating Value & $\mathrm{kJ} / \mathrm{g}$ & $15.8 \pm 0.5$ & $19.1 \pm 0.9$ & $18.4 \pm 0.1$ \\
\hline Particle size & $\mathrm{mm}$ & $2-15$ & $2-5$ & $10-30$ \\
\hline Bulk density & $\mathrm{g} / \mathrm{cm}{ }^{3}$ & $0.11 \pm 0.01$ & $0.3 \pm 0.01$ & $0.69 \pm 0.004$ \\
\hline Carbon & $\mathrm{Wt} \%$ & $44.0 \pm 0.24$ & $45.7 \pm 0.1$ & $48.05 \pm 0.05$ \\
\hline Hydrogen & $\mathrm{Wt} \%$ & $5.4 \pm 0.04$ & $5.72 \pm 0.03$ & $6.27 \pm 0.02$ \\
\hline Oxygen ${ }^{\mathrm{a}}$ & $\mathrm{Wt} \%$ & $48.2 \pm 0.4$ & $44.1 \pm 0.5$ & $45.33 \pm 0.09$ \\
\hline Nitrogen & $\mathrm{Wt} \%$ & $1.8 \pm 0.08$ & $1.8 \pm 0.03$ & $0.07 \pm 0.01$ \\
\hline Sulphur & $\mathrm{Wt} \%$ & $0.6 \pm 0.02$ & $1.1 \pm 0.01$ & $0.1 \pm 0.02$
\end{tabular}

\subsection{Experiment set-up}

The reactor consists of a base, and a reactor column, of $6.02 \mathrm{~cm}$ in diameter. The base houses the heating element (Incoloy-sheathed, $2.2 \times 4.2 \mathrm{~mm}$ cross-section), and an air diffuser (Figure 1). The base is filled with layers of gravel, then sand to provide uniformity of air flux. The column is clamped on top of the base, and a line of thermocouples runs down the centre of the reactor to record and monitor the temperature of the smouldering experiment. Feedstock is loaded from atop to fill $36 \mathrm{~cm}$ of the reactor. An additional $1 \mathrm{~cm}$ layer of clean sand is added on top of the feedstock to act as insulation [18]. 
After the setup is complete, the heater is turned on to initiate heating. Once the temperature at $2 \mathrm{~cm}$ above the heater reaches $250^{\circ} \mathrm{C}$ external heater is switched off and airflow is injected and adjusted using a mass flow controller (Cole-Parmer 32907-75). Self-sustaining smouldering combustion commences and propagates upwards. A more detailed description of the reactor design can be found in [5], [18].

Table 2 presents a summary of all experiments conducted. Each experiment was repeated 3 times. Gas samples were collected every 3 minutes and analysed via Gas Chromatography using a Perkin Elmer Gas Chromatograph Clarus $^{\circledR} 590$.

In experiments where heat losses overcome heat releases in the smouldering reaction, smouldering quenches and the experiment is described as non-self-sustaining smouldering (NSSS). In experiments close to the limits of self-sustainability, the reaction will consume most of the material in the reactor but may leave some unburnt material leftover such as char. These experiments are described as borderlineself-sustaining smouldering (BSSS). This classification is based on the work by Rashwan et al. [29].

Table 2. Material and operating conditions of smouldering experiments conducted $(\&=$ borderline-selfsustaining smouldering, \# = non-self-sustaining smouldering).

As shown in the literature, ER is an important parameter that affects the quality of the resulting gas fuels. Additional to ER, temperature is also an important parameter. The following experiments were conducted to assess the effects of certain operating parameters on ER and temperature, which in turn, affects the quality of the fuel gas produced from smouldering.

Nine experiments (exp. 1 - 9) were carried out to compare the impact of air flux and moisture content of the feedstock. The quality of gases is judged based on the characteristics of the gas, mainly gas composition, and energy content. To increase the uniformity of the materials, UCC and RBP samples were completely dried at $105^{\circ} \mathrm{C}$ and then the appropriate amount of water was added to the dried biomass, mixed, and stored in a sealed container for at least 24 hours before a smouldering experiment. Four experiments (exp. $10-13$ ) were conducted to determine the impact of oxygen content in the incoming airflow, diluting air with nitrogen on the production of gas fuels. Two experiments (exp. 14 and 15) were conducted to assess the effects of biomass dilution by adding inert sand, as in [18], [29], [30]. The sand was added during the moisture adjusting procedure. Finally, two more experiments (exp. 16 and 17) were conducted with a different feedstock (RBP or WP).

\subsection{Gas collection and analysis}

Eight gas samples were collected for each experiment, using a previously purged syringe. The gases were stored in airtight glass vials (Labco Extainers $12 \mathrm{~mL}$ ) for later gas chromatography (GC, Perkin Elmer Clarus $580 \mathrm{GC}$ ) analysis, where concentrations of $\mathrm{H}_{2}, \mathrm{CO}, \mathrm{CH}_{4}, \mathrm{CO}_{2}, \mathrm{~N}_{2}$, and $\mathrm{O}_{2}$ were analysed. The gas collection procedure is developed based on a gas sampling method by Sturm et al. [21]. The gas concentrations were normalized with respect to the product gases. 


\begin{tabular}{|c|c|c|c|c|c|c|}
\hline \multirow[t]{2}{*}{ Description } & \multirow[t]{2}{*}{ Exp. } & \multirow[t]{2}{*}{ Material } & \multicolumn{4}{|c|}{ Conditions } \\
\hline & & & $\begin{array}{l}M C \\
(\%)\end{array}$ & $\begin{array}{l}\text { Air flux } \\
(\mathrm{cm} / \mathrm{s})\end{array}$ & $\begin{array}{l}\text { Sand-to-biomass } \\
\text { ratio }(g / g)\end{array}$ & $\mathrm{O}_{2}(\%)$ \\
\hline \multirow{9}{*}{$\begin{array}{l}\text { Effect of moisture content and } \\
\text { air flux }\end{array}$} & 1 & UCC & 10 & 1.8 & - & 21 \\
\hline & 2 & UCC & 30 & 1.8 & - & 21 \\
\hline & 3 & UCC & 50 & 1.8 & - & 21 \\
\hline & 4 & UCC & 10 & 4 & - & 21 \\
\hline & 5 & UCC & 30 & 4 & - & 21 \\
\hline & 6 & UCC & 50 & 4 & - & 21 \\
\hline & 7 & UCC & 10 & 7.4 & - & 21 \\
\hline & 8 & UCC & 30 & 7.4 & - & 21 \\
\hline & 9 & UCC & 50 & 7.4 & - & 21 \\
\hline \multirow[t]{4}{*}{ Effect of $\mathrm{O}_{2}$ in airflow } & 10 & UCC & 50 & 7.4 & - & 14.8 \\
\hline & 11 & UCC & 50 & 7.4 & - & 11.2 \\
\hline & $12 \&$ & UCC & 50 & 7.4 & - & 5.8 \\
\hline & $13 \#$ & UCC & 50 & 7.4 & - & 3.6 \\
\hline \multirow{2}{*}{$\begin{array}{l}\text { Effect of sand addition } \\
\text { (dilution of biomass) }\end{array}$} & 14 & UCC & 50 & 7.4 & 4 & 21 \\
\hline & 15 & UCC & 50 & 7.4 & 8 & 21 \\
\hline \multirow[t]{2}{*}{ Effect of feedstock nature } & 16 & WP & 10 & 7.4 & - & 21 \\
\hline & 17 & RBP & 10 & 7.4 & - & 21 \\
\hline
\end{tabular}

\subsection{Calculations and assumptions}

The higher heating value $\left(\mathrm{HHV}_{\text {gas }}\right)$ of the product gases is calculated using Eq. (1) where $\mathrm{Y}_{\mathrm{x}}$ is the yield of species $x$ in (vol \%) and HHVx is the HHV of $x$ in $M J / \mathrm{Nm}^{3}$.

$\mathrm{HHV}$ of gas $\left(\mathrm{MJ} / \mathrm{Nm}^{3}\right):{ }^{H H V_{g a s}}=Y_{H_{2}}\left(H H V_{H_{2}}\right)+Y_{C O}\left(H H V_{C O}\right)+Y_{C_{4}}\left(H H V_{C H_{4}}\right)$

The air-to-fuel equivalence ratio was calculated following Eq. (2) [24]. The actual air-to-fuel ratio (numerator) was calculated considering $m_{\text {fuel }}$ as the amount of feedstock in the reactor and $m_{\text {air }}$ as the total amount of air injected into the reactor throughout an experiment (see Eq. (3)), where AF is the airflow and is the air density in standard conditions. The ER obtained in the paper should only be used 
indicatively to compare the experiments presented here and cannot be compared with gasification studies in the literature.

$E R=\frac{\left(\frac{m_{\text {air }}}{m_{\text {fuel }}}\right)_{\text {actual }}}{\left(\frac{m_{\text {air }}}{m_{\text {fuel }}}\right)_{\text {stoich }}}$

$m_{\text {air }}(g)=$ smould.duration $(\min ) * A F\left(\frac{m L}{m i n}\right) * \rho\left(\frac{g}{m L}\right)$

The smouldering duration is measured as the duration of experiment from ignition to the time when all thermocouples start decreasing (when $\mathrm{dT} / \mathrm{dt}<0$ ). The average peak temperature for each experiment was calculated as the average between the peak of each four thermocouples located in the oxidation zone under steady-state conditions (see section 3.2 for a more detailed explanation on steady-state stage).

\section{Results And Discussion}

\subsection{Characterization of raw material by TGA and DSC}

Figure 3 presents the Thermogravimetric (TG), first-order derivative thermogravimetric (DTG), and differential scanning calorimetry (DSC) curves obtained from Thermogravimetric Analysis (TGA) of the three raw materials used. A small peak at $100{ }^{\circ} \mathrm{C}$ visible on the DTG on each atmosphere corresponds to the evaporation of water, also visible on the DSC as an endothermic peak.

Both DTG plots in Figure 3a and 3c showed a peak between $200-400{ }^{\circ} \mathrm{C}$ that represents the devolatilization of hemicellulose and cellulose [31], [32]. Under inert nitrogen atmosphere (Figure 3b), relatively small endothermic DSC peaks can be seen at ca. $380^{\circ} \mathrm{C}$. Nevertheless, under oxidative atmosphere (Figure 3d), the DSC peaks are exothermic. This is due to oxidation reactions of the released volatiles, which is highly exothermic [33].

The third main component of these lignocellulosic materials is lignin, which slowly decomposes over a wide range of temperatures [31], [32]. Therefore, this process does not show up as a prominent peak in the DTG curves, but as a steady mass decomposition, starting at $200^{\circ} \mathrm{C}$ and lasting until the end of the experiment.

The main difference between the experiments in both atmospheres is the presence of strong peaks between $400-600{ }^{\circ} \mathrm{C}$ under air atmosphere (Figure 3c). This peak represents the oxidation of residue left after devolatilization of the material, also known as char [31], [32]. Kok et al. reported that the oxidation of char provides the bulk of the energy released from the combustion of biomass, hence the larger exothermic peak [33]. 
Ohlemiller stated that the main source of energy in smouldering combustion is the heterogeneous oxidation of char [1]. This char oxidation is viewed as the exothermic peaks in the DSC (Figure 3d). While the UCC has the largest peak out of the three materials, the HHV obtained via bomb calorimetry, showed that WP and RBP have a higher calorific content (18.4 and $19.1 \mathrm{~kJ} / \mathrm{g}$ respectively) compared to UCC (15.8 $\mathrm{kJ} / \mathrm{g}$ ). This means that, under stoichiometric conditions, the burning WP and RBP will release more heat than UCC and result in higher temperatures. However, during smouldering processes, since the oxidation of chars provides the main source of energy for the reaction to self-sustain, this suggests that smouldering of UCC will result in higher temperatures and lower production of volatile gases compared to RBP and WP. These results are discussed later in the paper when the smouldering experiments' results are presented.

Finally, TGA results showed that the exothermic thermal degradation of these materials starts just above $200^{\circ} \mathrm{C}$ and therefore, a temperature of $250^{\circ} \mathrm{C}$ (registered at the lowest thermocouple) has been chosen as the temperature when the airflow is initiated and the heating is ceased [30].

\subsection{Smouldering of UCC: general observations.}

Figure 4a presents an example of the temperature-time plots from a UCC smouldering experiment. Figure $4 \mathrm{~b}$ shows the evolution of gas composition of the smouldering gases as a function of time. Several stages can be identified, with each having different characteristics. The stages are named: heating (I), ignition (II), steady-state smouldering (III), burn-out (IV), and cooling (V). In all cases, the exhaust gas temperature was measured with a thermocouple placed at $40 \mathrm{~cm}$ from the heater (bed height was 37 $\mathrm{cm})$.

Stage $I$ is the heating stage where feedstock near the heater is heated to ignition temperatures. Feedstock typically plateaus at $100^{\circ} \mathrm{C}$ as water evaporates. Therefore, the extent of this plateau depends on the moisture content, as well as on the characteristic of the material (thermal conductivity, density), and heating rate (however, this is constant for all experiments) [18].

Stage II commences when the airflow is initiated (when the thermocouple at $2 \mathrm{~cm}$ above the heater reaches $250^{\circ} \mathrm{C}$ ). The temperature rises rapidly due to the exothermic oxidation of the material. In this stage, the rate of temperature rise is highly dependent on the air flux [3]. Temperatures at the exhaust increases slightly to between $60-85^{\circ} \mathrm{C}$, and oxygen content in the gases drops to its minimum content as oxygen is being consumed by the reactions occurring in the reactor. Mass rate also starts to increase as fuel is being consumed.

Stage III is characterized by a quasi-steady-state smouldering process. Here, the fuel and oxygen consumptions, mass loss, and yield of gas products, are at their highest. Gas samples presented in the results section are obtained from this stage of the smouldering experiments. Mass was not measured in this study, however, the low oxygen content in the gas samples shows that material is being consumed and converted into gas products, and mass loss rate could be assumed to be high and constant [29]. 
Temperatures of the exhaust gas varies between $70-85^{\circ} \mathrm{C}$ for nearly all experiments with an exception to experiments with sand mixed into the fuel bed with exhaust temperatures averaging just below $60^{\circ} \mathrm{C}$. The exhaust temperatures are affected by the thermal conductivity and specific heat capacity of the fuel bed since heat is absorbed by the upper layers of the fuel bed as hot gases produced from the oxidation zone (or smouldering front) travels upwards [3], [13]. In the series of experiment conducted for this study, the feedstocks have varying moisture content and particle size, which affect bed conductivity, but it is the addition of sand that caused a decrease in exhaust temperature. This suggests that in these series of experiments, specific heat capacity of the fuel bed may have a stronger effect on exhaust temperature compared to thermal conductivity.

Stage IV is where the solid burn-out takes place. Exhaust temperature increases (up to $300{ }^{\circ} \mathrm{C}$ ) as the upper layers of the bed starts to thin. A phenomenon called "bridging" may occur when the bed of material is smouldered but feedstock residue is present in the upper part of the column [34], [35]. Stage IV ends when all the organic material in the reactor is consumed.

During Stage V, the reactor cools down as there are no chemical reactions taking place. For practical purposes, once all registered temperatures reached $200^{\circ} \mathrm{C}$, it is considered the end of the experiment as most thermochemical reaction ceases (as seen in the TGA).

\subsection{Smouldering of UCC: effect of major operational parameters}

\subsubsection{Effect of air flux}

An increase in air flux increases oxygen flow to the oxidation zone and increases exothermic reactions resulting in higher temperatures (Figure 5a). The higher temperatures caused by the increased in oxygen flow also cause an increase in reaction rates which results in a low $\mathrm{O}_{2}$ concentration in the gas products (Figure 5b).

Higher temperatures promote the devolatilization of lignocellulosic biomass and cracking of tar (longchained hydrocarbons) into smaller chains (such as $\mathrm{CH}_{4}$ ) and other useful products (such as $\mathrm{H}_{2}$ and C0) [36]. Higher temperatures also favours endothermic reactions such as the water-gas reaction ( ) and methane reforming reactions (steam: , and dry reforming: ) for production of syngas [37]-[43]. Results from Figure 6 suggest dry reforming, which occurs at temperatures above $700{ }^{\circ} \mathrm{C}$ [44] could be taking place as it shows a slight increase in $\mathrm{H}_{2}$ and $\mathrm{CO}$ and a decrease in $\mathrm{CO}_{2}$ concentration when air flux was increased. However, no significant trend is observed for $\mathrm{CH}_{4}$ concentration.

Results showed that the ER is not affected by air flux in any significant way (Figure $5 b$ ). An explanation is provided by observing the smouldering duration for each experiment. As air flux increases, assuming duration stays the same, the total amount of air injected into the reactor increases. As shown on Eq. (2), 
ER is calculated by dividing the actual air-to-fuel ratio by the stoichiometric air-to-fuel ratio. Therefore, ER is expected to increase along with air flux. However, smouldering duration, and therefore smouldering velocity is highly affected by the air flux. Similar observations were made by Yermán et al. [45] and Switzer et al. [3] where a linear proportion between air flux and smouldering velocity is reported. Since $m_{\text {air }}$ is calculated from smouldering duration (Eq. (3)), $m_{\text {air }}$ is left unchanged as a result of the proportional decrease of the smouldering duration due to the increase in air flux, and ER stays constant with changes in air flux.

The importance of ER is extensively covered in the literature, which makes it important in these smouldering experiments to manipulate the operating parameters to obtain a condition where reduction reactions are prioritized. Since air flux is shown not to affect ER in any significant way, other parameters are altered to achieve this goal.

\subsubsection{Effect of moisture content}

As the moisture content increases from 10 to $50 \%$, a diminution in smouldering temperatures (beyond the error bars) is observed only be significant at higher air fluxes (Figure 5a). Water acts as a heat sink, and therefore it is expected to see some diminution in the smouldering temperature [46], [47]. Yermán et al [30] showed that the smouldering temperatures remained approximately constant with the changes in the MC from 64 to $73 \%$ for the smouldering of artificial faeces mixed with sand at a fixed and relatively low air flux $(3 \mathrm{~cm} / \mathrm{s})$. The same result is observed here at lower air fluxes. Chen et al. [48] reported with experiments conducted in a fixed-bed gasifier running with around $4.1 \mathrm{~cm} / \mathrm{s}$ air flux that an increase in moisture from 12.6 to $20.14 \%$ decreased the peak temperature of the reactor from 1094 to $1014{ }^{\circ} \mathrm{C}$ due to energy required to evaporate moisture in the feedstock.

Regarding the gas products, Huchon et al. [49] showed that an increase in feedstock moisture content from 11 to $23 \%$ in a fixed bed gasification reactor decreases the overall efficiency of the system and reduced the lower heaving value (LHV) of the product gas. This was caused by a decrease in $\mathrm{CO}$ and $\mathrm{CH}_{4}$ and an increase in $\mathrm{CO}_{2}$ in the product gas. Figure 5 shows that an increase in moisture content has a slight increase in $\mathrm{H}_{2}$ and decrease in $\mathrm{CO}$ concentrations. The slight increase in $\mathrm{H}_{2}$ can be explained by the water gas shift (WGS) reaction () occurring near the smouldering front, around $300{ }^{\circ} \mathrm{C}$ [24]. While there is no water present as the material is dried at this temperature, $\mathrm{H}_{2} \mathrm{O}$ is formed during the oxidation of the material ). This oxidation takes place at higher temperatures, in the smouldering front, which is situated below the WGS zone; and therefore this might be responsible for the slight increase in the WGS reaction and $\mathrm{H}_{2}$ concentration [49].

The high ER reported in these experiments $(0.43-0.80)$ compared to typical values in gasification (0.2 0.4) [24] is reflected in the $\mathrm{CO}_{2}$ concentration in the gases. A high ER reflects a highly oxidative atmosphere in the reactor with more oxidation reactions occurring. Higher oxidation reactions consume 
fuel and releases $\mathrm{CO}_{2}$ and heat resulting in a poor-quality fuel gas (high $\mathrm{CO}_{2}$, low $\mathrm{H}_{2}, \mathrm{CO}$, and $\mathrm{CH}_{4}$ ). Since the change in moisture content does not have any positive effects on ER,

\subsubsection{Effect of oxygen concentration}

Experiments with lower oxygen concentration were carried out in an attempt to reduce the ER and to assess its effects on ER and average peak temperature, which in turn, affects gas concentration and HHV. The results are presented on Figure 7. Smouldering experiments are conducted with and air flux of 7.4 $\mathrm{cm} / \mathrm{s}$ and feedstock at $50 \%$ moisture content.

A decrease in the oxygen concentration in the air flux causes a decrease in average peak temperature (Figure $7 \mathrm{~b}$ ) and smouldering velocity (data not shown). With decreasing amount of $\mathrm{O}_{2}$ flowing into the oxidation zone, average peak temperatures decrease up to a point where smouldering becomes non-selfsustaining (Figure 7b). The decreased smouldering temperature had a detrimental impact to the quality of gas products, which decreases concentrations of $\mathrm{H}_{2}$ and $\mathrm{HHV}$ while concentrations of $\mathrm{CO}_{2}$ increases (Figure 7a). There was not enough heat to support the endothermic reactions needed to produce fuel gas. The concentration of $\mathrm{CO}$ stayed relatively constant even when the reaction is non-self-sustaining. This reflects that smouldering is characteristically oxygen-limited and $\mathrm{CO}$ produced from smouldering will always be higher compared to flaming combustion [1], [4].

The decrease in $\mathrm{O}_{2}$ content in the airflow was intended to decrease oxidation and promote reduction reactions in the reactor. Based on Eq. (2), lower amount of $\mathrm{O}_{2}$ decreases $\mathrm{m}_{\text {air }}$ in the $\left(\mathrm{m}_{\text {air }} / \mathrm{m}_{\text {fuel }}\right)_{\text {actual }}$, which in turns decreases ER. This did not happen in practice as ER increases when $\mathrm{O}_{2}$ concentration decreases as evident on Figure $7 \mathrm{~b}$. This occurs since smouldering velocity decreases, duration of smouldering increases which in turns, increases $m_{\text {air }}$ and effectively increased $E R$, up to above one. This shows that ER cannot be compared to values obtained in the literature, and in this case, used only indicatively.

\subsubsection{Effect of solid dilution (addition of sand)}

Figure 8 presents gas concentration and HHV, average peak temperature, and ER results of smouldering experiments conducted at two different sand-to-waste mass ratios (4 and $8 \mathrm{~g} / \mathrm{g}$ ), at $50 \%$ moisture content and $7.4 \mathrm{~cm} / \mathrm{s}$ air flux, and its comparison with experiments using no sand (sand-to-waste mass ratio $=0)$.

$\mathrm{HHV}$ was left unchanged as S:W ratio increases from 0 (no sand) to 4 . However, concentrations of $\mathrm{H}_{2}$ and $\mathrm{CH}_{4}$ decreases, while the ratio between $\mathrm{CO} / \mathrm{CO}_{2}$ increases. This suggests a decrease in oxidation reactions. This is supported by the decrease in average peak temperature. Further increase of $\mathrm{S}: \mathrm{W}$ ratio from 4 to 8 however, decreases quality of gas fuels and increases concentrations of $\mathrm{CO}_{2}$. This trend 
shows that the addition of sand has altered the texture and thermal properties of the fuel bed, which in turn affected the contact between $\mathrm{O}_{2}$ and the fuel [50]. It is possible that when $\mathrm{S}: \mathrm{W}$ ratio is increased to 8 , the sand provided better contact between $\mathrm{O}_{2}$ and the feedstock, which increases oxidation reactions and as a result, increases $\mathrm{CO}_{2}$ concentration and decreases $\mathrm{HHV}$. This is supported by the increase of ER.

Based on (Eq. (2)), adding sand decreases $m_{\text {fuel }}$, resulting in an increase of $E R$, which is an undesirable effect. However, higher air flux is balanced by shorter smouldering duration, which keeps ER constant. A similar effect could happen here, as a lower amount of fuel $\left(\mathrm{m}_{\mathrm{fuel}}\right)$ shorten smouldering duration (data not shown), which also keeps ER constant. The only exception is for the experiment with a sand-to-waste ratio of $8 \mathrm{~g} / \mathrm{g}$. The experiment are longer compared to experiments of $4 \mathrm{~g} / \mathrm{g}$. This, along with the lowered amount of fuel in the reactor resulted in an increase in ER (to above one). An ER of above one means that the environment in the reactor is above stoichiometry, which means that all fuel should have been converted to $\mathrm{CO}_{2}$. The fact that there is still a small amount of fuel gas in the gas products $\left(\mathrm{H}_{2}, \mathrm{CO}\right.$, and $\mathrm{CH}_{4}$ ) shows the unreliability of ER from a smouldering perspective, and the ER in this context should only be used indicatively to compare between experiments.

By adding sand into the fuel bed, the fuel is diluted by the sand. This effectively has a similar effect of increasing the ash content of the fuel bed and reducing every other parameter in the proximate analysis (including HHV of the feedstock). This lowers the amount of fuel available in the reactor and acts as a heat sink. The heat sink can be beneficial as it allows the development of a steadier smouldering front. This has also been observed in the literature [50]. Since there is a lot more inert material in the fuel bed, the smouldering front is observed travelling upwards through the fuel bed (data not shown).

While adding sand into the fuel bed has also been applied to provide the necessary porosity for uniform distribution of oxygen to the smouldering front [50], it is typically done to a pasty feedstock that does not have the required porosity [5], [18], [30]. UCC, even at high moisture content (up to $85 \%$ ) is a very porous material and does not benefit from the addition of sand as shown on Figure 8. Experiment conducted at $75 \%$ moisture content with S:W ratio demonstrates that the addition of sand will quenches the experiment when normally without sand, the smouldering would have been self-sustaining (data not shown).

\subsection{Smouldering of other lignocellulosic material}

The two additional materials tested in this section (WP and RBP) has higher volatile matter, energy content and bulk density compared to UCC. Despite these characteristics, the smouldering of WP and RBP occurs at lower temperatures compared to UCC (Figure 9b). This emphasizes the concept that a solid with higher HHV does not necessary produces higher temperatures when smouldering. As explained in Section 3.1, the energy used to sustain smouldering is given by the exothermic oxidation of the char left after pyrolysis. This is not considered in the HHV as tests to determine HHV (bomb calorimetry) does not differentiate between exothermic reactions from char or volatiles. 
The smouldering of WP produced more $\mathrm{H}_{2}, \mathrm{CO}$, and $\mathrm{CH}_{4}$, and less $\mathrm{CO}_{2}$, resulting in a higher $\mathrm{HHV}$ value compared to UCC. On the other hand, the smouldering of RBP resulted in slightly higher $\mathrm{H}_{2}$ concentration (however within error bars), but a lower $\mathrm{CO}$ and $\mathrm{CH}_{4}$ concentrations, resulting in lower HHV. As lignocellulosic material is heated, the material devolatilises, and volatile matter leaves the material as long chain hydrocarbon condensing in the upper cooler portions of the bed waste, as tars [51]. At some point, the smouldering front reaches these tars, when they can be broken down into smaller molecules in an endothermic process known as cracking of tar [24], [52]; leading to an increased in HHV in the gases. As WP and RBP has higher volatile matter, which in turn, results in higher condensation of tar in the upper layers of wastes, a higher concentration of $\mathrm{H}_{2}$, and $\mathrm{CH}_{4}$ is observed in the product gases for experiments at $7.4 \mathrm{~cm} / \mathrm{s}$.

A higher production of tar from higher bulk density of feedstock has been reported in a top-lit updraft biomass gasifier, which involves a smouldering process [38]. This is presumably what is occurring in the smouldering of WP, which has a bulk density almost seven times higher than the UCC.

This can be explained by some feedstock characteristics. For example, WP has a much larger particle size compared to UCC (10 - $30 \mathrm{~mm}$ and $2-15 \mathrm{~mm}$, respectively), while particle size of RBP sits between UCC and WP. The larger particle size, along with higher bulk density resulted in significant lower smouldering velocities of WP and RBP compared to UCC. This was observed by Pironi et al. in the smouldering of NAPL mixed with sand [14] and Yermán et al. in the smouldering of faeces with sand [18]. Smouldering experiments shows that average peak temperature increases when mean grain size (of the sand mixed in with the NAPL) increases from 0.75 to $1.34 \mathrm{~mm}$ but decreases when grain sizes further increase from 1.34 to $10 \mathrm{~mm}$ down to a point where the smouldering becomes non-self-sustaining and quenches.

In addition, gasification between rice hulls and woodchips was compared [38]. Woodchips had higher bulk density, particle size, and carbon content, and lower ash content compared to rice hulls. The gasification of rice hulls was shown to produce more $\mathrm{H}_{2}$ compared to woodchips. The author claims that while a lower ash content corresponds to woodchips having relatively more organic material, a higher bulk density and particle size causes woodchips to have a slower smouldering rate allowing rice hulls to reach higher temperatures. The difference in HHV between the two material however was not reported or discussed.

\section{Conclusion}

This study shows that there is potential to produce fuel gas with best conditions $(7.4 \mathrm{~cm} / \mathrm{s}$ air flux, $10 \%$ feedstock moisture content) producing gas fuels with concentrations of $\mathrm{H}_{2}, \mathrm{CO}, \mathrm{CH}_{4}$, and $\mathrm{CO}_{2}$ at 7.7, 32.6, 2.3 , and $57.4 \%\left(\mathrm{~N}_{2}\right.$ free), respectively. A HHV of $1.82 \mathrm{MJ} / \mathrm{Nm}^{3}$ was achieved. The dilution of oxygen, and fuel using nitrogen and sand respectively does not improve smouldering products, although the addition of sand allowed for more steady smouldering front. Smouldering of WP and RBP shows that the characteristics of the fuel have a large impact on the characteristics of the smouldering experiment. Even 
though WP and RBP has a higher HHV compared to UCC, higher temperatures are achieved with UCC. With a moisture content of $10 \%$ and air flux of $7.4 \mathrm{~cm} / \mathrm{s}$, the smouldering of WP and RBP were able to produce gas products with gas concentrations 8.8 and $10.2 \%$ of $\mathrm{H}_{2}, 32.2,24.9 \%$ of $\mathrm{CO}, 5.7,3.0 \%$ of $\mathrm{CH} 4$, and 53.7 , and $61.1 \%\left(\mathrm{~N}_{2}\right.$ free $)$ of $\mathrm{CO}_{2}$, respectively.

This study describes a proof-of-concept that demonstrates the potential for the production of fuel gas alongside waste treatment of agricultural waste by means of self-sustaining smouldering without the need of additional heating/fuel. Further experimental work is necessary to develop optimum operating conditions to improve the fuel gas quality, yield, and for a range of waste feedstock with different chemical composition.

\section{Declarations}

Funding: not applicable

Conflicts of interest/Competing interests: not applicable

Availability of data and material: not applicable

Code availability: not applicable

Author's contribution: All authors whose names appear on the submission have made substantial contributions to the conception or design of the work, drafted/revised the work critically for important intellectual content, approved the version to be published, and agree to be accountable for all aspects of the work.

Ethics approval: not applicable

Consent to participate: not applicable

Consent for publication: not applicable

Data availability statement

Data sharing not applicable to this article as no datasets were generated or analysed during the current study.

\section{References}

[1] T. J. Ohlemiller, "Modeling of smoldering combustion propagation," Prog. Energy Combust. Sci., vol. 11, no. 4, pp. 277-310, 1985.

[2] G. Rein, "Smoldering Combustion," in SFPE Handbook of Fire Protection Engineering, M. J. Hurley, D. Gottuk, J. R. Hall, K. Harada, E. Kuligowski, M. Puchovsky, J. Torero, J. M. Watts, and C. Wieczorek, Eds. 
New York, NY: Springer New York, 2016, pp. 581-603.

[3] C. Switzer, P. Pironi, J. I. I. Gerhard, G. Rein, and J. L. L. Torero, "Volumetric scale-up of smouldering remediation of contaminated materials," J. Hazard. Mater., vol. 268, no. Supplement C, pp. 51-60, 2014.

[4] G. Rein, "Smouldering Combustion Phenomena in Science and Technology," Int. Rev. Chem. Eng., vol. 1, p. 22, 2009.

[5] L. Yermán, "Self-sustaining Smouldering Combustion as a Waste Treatment Process," in Developments in Combustion Technology, K. G. Kyprianidis and J. Skvaril, Eds. Rijeka: InTech, 2016, p. Ch. 06.

[6] Y. Tang, Q. Guo, and L. Yermán, "Experimental Investigation on Using Chloride/Hydroxide Aerosol to Control Spontaneous Combustion of Lignite in Underground Coal Mines," Energy and Fuels, vol. 34, no. 9, pp. 10607-10618, 2020.

[7] A. Bar-Ilan, G. Rein, A. C. Fernandez-Pello, J. L. Torero, and D. L. Urban, “Forced forward smoldering experiments in microgravity," Exp. Therm. Fluid Sci., vol. 28, no. 7, pp. 743-751, 2004.

[8] T. J. Ohlemiller, "Smouldering Combustion," in SFPE Handbook of Fire Protection Engineering, P. J. DiNenno, D. Drysdale, C. L. Beyler, and W. D. Walton, Eds. National Fire Protection Association, 2008, pp. 2-210.

[9] K. N. Palmer, "Smouldering combustion in dusts and fibrous materials," Combust. Flame, vol. 1, no. 2, pp. 129-154, 1957.

[10] J. Torero, "Buoyancy Effects on Smoldering of Polyurethane Foam," University of California at Berkeley, 1992.

[11] G. P. Grant et al., "Smoldering Combustion (STAR) for the Treatment of Contaminated Soils: Examining Limitations and Defining Success," Remediat. J., vol. 26, no. 3, pp. 27-51, Jun. 2016.

[12] J. L. Torero, J. I. Gerhard, L. L. Kinsman, and L. Yermán, "Using fire to remediate contaminated soils," Undergr. Coal Gasif. Combust., pp. 601-625, Jan. 2018.

[13] C. Switzer, P. Pironi, J. I. I. Gerhard, G. Rein, and J. L. L. Torero, "Self-Sustaining Smoldering Combustion: A Novel Remediation Process for Non-Aqueous-Phase Liquids in Porous Media," Environ. Sci. Technol., vol. 43, no. 15, pp. 5871-5877, 2009.

[14] P. Pironi, C. Switzer, J. I. Gerhard, G. Rein, and J. L. Torero, "Self-Sustaining Smoldering Combustion for NAPL Remediation: Laboratory Evaluation of Process Sensitivity to Key Parameters," Environ. Sci. Technol., vol. 45, no. 7, pp. 2980-2986, 2011.

[15] P. Pironi, C. Switzer, G. Rein, A. Fuentes, J. I. Gerhard, and J. L. Torero, "Small-scale forward smouldering experiments for remediation of coal tar in inert media," Proc. Combust. Inst., vol. 32, no. 2, 
pp. 1957-1964, 2009.

[16] G. Sabadell et al., "Ex situ treatment of organic wastes or oil-impacted soil using a smoldering process," WIT Trans. Ecol. Environ., vol. 231, pp. 367-376, 2019.

[17] G. C. Scholes et al., "Smoldering Remediation of Coal-Tar-Contaminated Soil: Pilot Field Tests of STAR," Environ. Sci. Technol., vol. 49, no. 24, pp. 14334-14342, 2015.

[18] L. Yermán et al., "Smouldering combustion as a treatment technology for faeces: Exploring the parameter space," Fuel, vol. 147, pp. 108-116, 2015.

[19] H. K. Wyn, M. Konarova, J. Beltramini, G. Perkins, and L. Yermán, "Self-sustaining smouldering combustion of waste: A review on applications, key parameters and potential resource recovery," Fuel Process. Technol., vol. 205, p. 106425, Aug. 2020.

[20] L. Yermán, J. Carrascal, J. L. L. Torero, I. Fabris, D. Cormier, and J. I. I. Gerhard, "Smouldering combustion as a treatment for human waste," in 5th International Symposium on Energy from Biomass and Waste, 2014, pp. 1-18.

[21] H. K. Wyn, S. Zárate, J. Carrascal, and L. Yermán, "A Novel Approach to the Production of Biochar with Improved Fuel Characteristics from Biomass Waste," Waste and Biomass Valorization, Dec. 2019.

[22] J.-P. Vantelon, B. Lodeho, S. Pignoux, J. L. Ellzey, and J. L. Torero, "Experimental observations on the thermal degradation of a porous bed of tires," Proc. Combust. Inst., vol. 30, no. 2, pp. 2239-2246, 2005.

[23] L. Yermán et al., "Potential Bio-oil Production from Smouldering Combustion of Faeces," Waste and Biomass Valorization, vol. 8, no. 2, pp. 329-338, 2017.

[24] P. Basu, Biomass Gasification, Pyrolysis and Torrefaction: Practical Design and Theory, 2nd ed. Elsevier, 2013.

[25] V. S. Sikarwar, M. Zhao, P. S. Fennell, N. Shah, and E. J. Anthony, "Progress in biofuel production from gasification," Prog. Energy Combust. Sci., vol. 61, pp. 189-248, 2017.

[26] Y. Richardson, M. Drobek, A. Julbe, J. Blin, and F. Pinta, Biomass Gasification to Produce Syngas. 2015.

[27] ASTM, "ASTM E1131 - 08. Standard Test Method for Compositional Analysis by Thermogravimetry," 2015.

[28] ASTM, "ASTM E873-82. Standard Test Method for Bulk Density of Densified Particulate Biomass Fuels," 2019.

[29] T. L. Rashwan, J. I. Gerhard, and G. P. Grant, "Application of self-sustaining smouldering combustion for the destruction of wastewater biosolids," Waste Manag., vol. 50, no. Supplement C, pp. 201-212, 
2016.

[30] L. Yermán, H. Wall, J. Torero, J. I. Gerhard, and Y. L. Cheng, "Smoldering Combustion as a Treatment Technology for Feces: Sensitivity to Key Parameters," Combust. Sci. Technol., vol. 188, no. 6, pp. 968$981,2016$.

[31] C. Di Blasi and C. Branca, "Global degradation kinetics of wood and agricultural residues in air," Can. J. Chem. Eng., vol. 77, no. 3, pp. 555-561, Jun. 1999.

[32] H. Chen, N. Liu, and W. Fan, "Two-step Consecutive Reaction Model of Biomass Thermal Decomposition by DSC," Acta Physico-Chimica Sin., vol. 22, no. 7, pp. 786-790, 2006.

[33] M. V. Kok and E. Özgür, "Thermal analysis and kinetics of biomass samples," Fuel Process. Technol., vol. 106, pp. 739-743, 2013.

[34] C. D. Di Blasi, G. Signorelli, and G. Portoricco, "Countercurrent fixed-bed gasification of biomass at laboratory scale," Ind. Eng. Chem. Res., vol. 38, no. 7, pp. 2571-2581, 1999.

[35] Y. Ueki, T. Torigoe, H. Ono, R. Yoshiie, J. H. Kihedu, and I. Naruse, "Gasification characteristics of woody biomass in the packed bed reactor," Proc. Combust. Inst., vol. 33, no. 2, pp. 1795-1800, 2011.

[36] M. Milhé, L. van de Steene, M. Haube, J.-M. Commandré, W.-F. Fassinou, and G. Flamant, "Autothermal and allothermal pyrolysis in a continuous fixed bed reactor," J. Anal. Appl. Pyrolysis, vol. 103, pp. 102-111, 2013.

[37] A. Seçer, N. Küçet, E. Fakı, and A. Hasanoğlu, "Comparison of co-gasification efficiencies of coal, lignocellulosic biomass and biomass hydrolysate for high yield hydrogen production," Int. J. Hydrogen Energy, vol. 43, no. 46, pp. 21269-21278, 2018.

[38] A. M. James R, W. Yuan, M. D. Boyette, and D. Wang, "Airflow and insulation effects on simultaneous syngas and biochar production in a top-lit updraft biomass gasifier," Renew. Energy, vol. 117, pp. 116124, Mar. 2018.

[39] C. Gai and Y. Dong, "Experimental study on non-woody biomass gasification in a downdraft gasifier," Int. J. Hydrogen Energy, vol. 37, no. 6, pp. 4935-4944, Mar. 2012.

[40] M. Seggiani, M. Puccini, G. Raggio, and S. Vitolo, "Effect of sewage sludge content on gas quality and solid residues produced by cogasification in an updraft gasifier," Waste Manag., vol. 32, no. 10, pp. 1826-1834, 2012.

[41] A. L. Galindo, E. S. Lora, R. V. Andrade, S. Y. Giraldo, R. L. Jaén, and V. M. Cobas, “Biomass gasification in a downdraft gasifier with a two-stage air supply: Effect of operating conditions on gas quality," Biomass and Bioenergy, vol. 61, pp. 236-244, 2014. 
[42] M. Seggiani, S. Vitolo, M. Puccini, and A. Bellini, "Cogasification of sewage sludge in an updraft gasifier," Fuel, vol. 93, pp. 486-491, Mar. 2012.

[43] F. Guo, Y. Dong, L. Dong, and C. Guo, "Effect of design and operating parameters on the gasification process of biomass in a downdraft fixed bed: An experimental study," Int. J. Hydrogen Energy, vol. 39, no. 11, pp. 5625-5633, Apr. 2014.

[44] R. Maurya, S. R. Tirkey, S. Rajapitamahuni, A. Ghosh, and S. Mishra, "Chapter 9 - Recent Advances and Future Prospective of Biogas Production," in Woodhead Publishing Series in Energy, M. B. T.-A. in F. C. T. for A. F. and B. Hosseini, Ed. Woodhead Publishing, 2019, pp. 159-178.

[45] L. Yermán, H. Wall, and J. L. Torero, "Experimental investigation on the destruction rates of organic waste with high moisture content by means of self-sustained smoldering combustion," Proc. Combust. Inst., vol. 36, no. 3, pp. 4419-4426, 2017.

[46] P. Basu, "Chapter 3 - Biomass Characteristics," in Biomass Gasification, Pyrolysis and Torrefaction (Second Edition), P. Basu, Ed. Boston: Academic Press, 2013, pp. 47-86.

[47] A. A. P. Susastriawan, H. Saptoadi, and Purnomo, "Small-scale downdraft gasifiers for biomass gasification: A review," Renew. Sustain. Energy Rev., vol. 76, pp. 989-1003, 2017.

[48] R. Yin, R. Liu, J. Wu, X. Wu, C. Sun, and C. Wu, "Influence of particle size on performance of a pilotscale fixed-bed gasification system," Bioresour Technol, vol. 119, pp. 15-21, 2012.

[49] V. Huchon, F. Pinta, J. M. Commandré, and L. Van De Steene, "How electrical engine power load and feedstock moisture content affect the performance of a fixed bed gasification genset," Energy, vol. 197, pp. 2-11, 2020.

[50] G. Gianfelice, M. Della Zassa, A. Biasin, and P. Canu, "Onset and propagation of smouldering in pine bark controlled by addition of inert solids," Renew. Energy, vol. 132, pp. 596-614, 2019.

[51] M. U. Monir, A. Abd Aziz, R. A. Kristanti, and A. Yousuf, "Gasification of lignocellulosic biomass to produce syngas in a $50 \mathrm{~kW}$ downdraft reactor," Biomass and Bioenergy, vol. 119, pp. 335-345, Dec. 2018.

[52] N. Mahinpey and A. Gomez, "Review of gasification fundamentals and new findings: Reactors, feedstock, and kinetic studies," Chem. Eng. Sci., vol. 148, pp. 14-31, 2016.

\section{Figures}




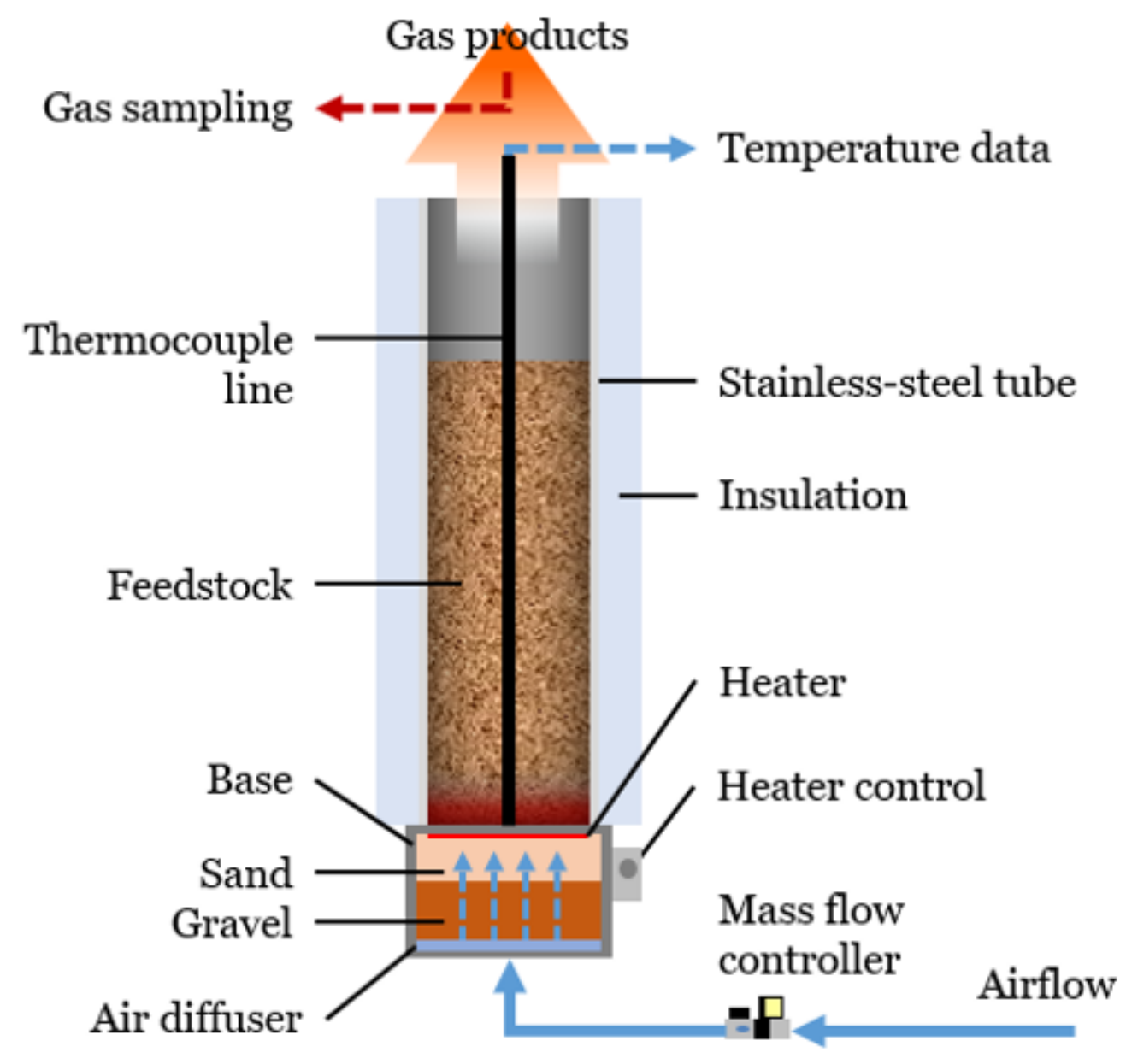

Figure 1

Typical reactor set-up used for soil remediation and/or waste treatment (adapted from [18]).

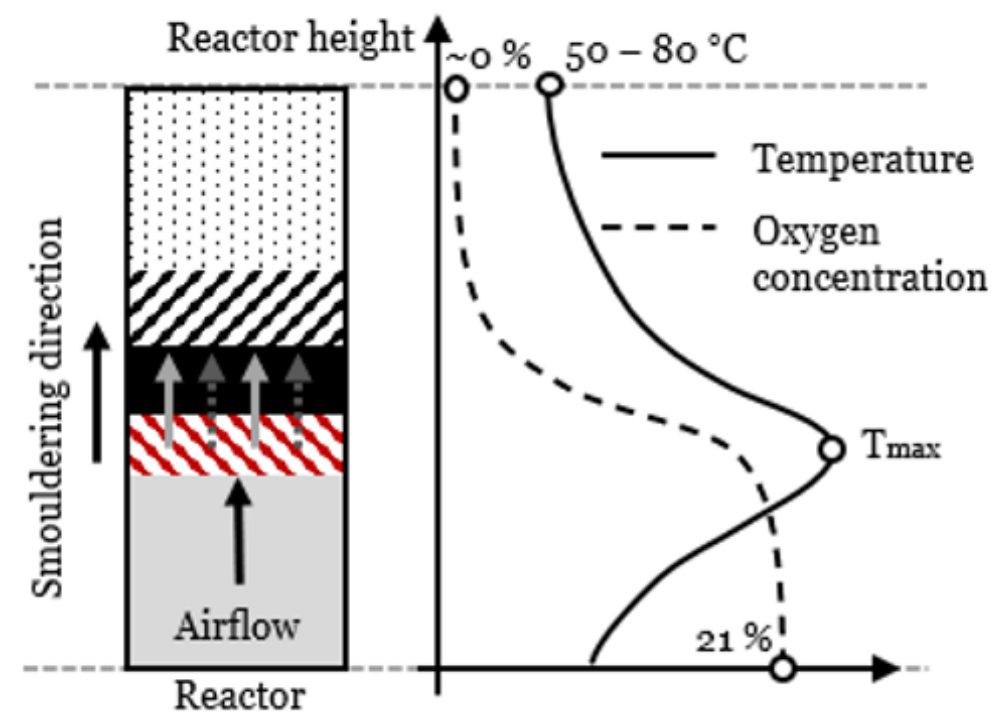

\begin{tabular}{|ll|}
\hline$\vdots$ & Radiative heating \\
1 & Hot airflow, convective heating \\
$\square$ & No reaction (Water re-condensation) \\
$\square$ & Pre-heating/Drying zone \\
⿴囗十 & Pyrolysis zone \\
$\square$ & Oxidation zone (smouldering front) \\
\hline
\end{tabular}

Figure 2 
Processes in a smouldering reactor in the forwards upwards smouldering configuration (adapted from Yermán et al. [20]).
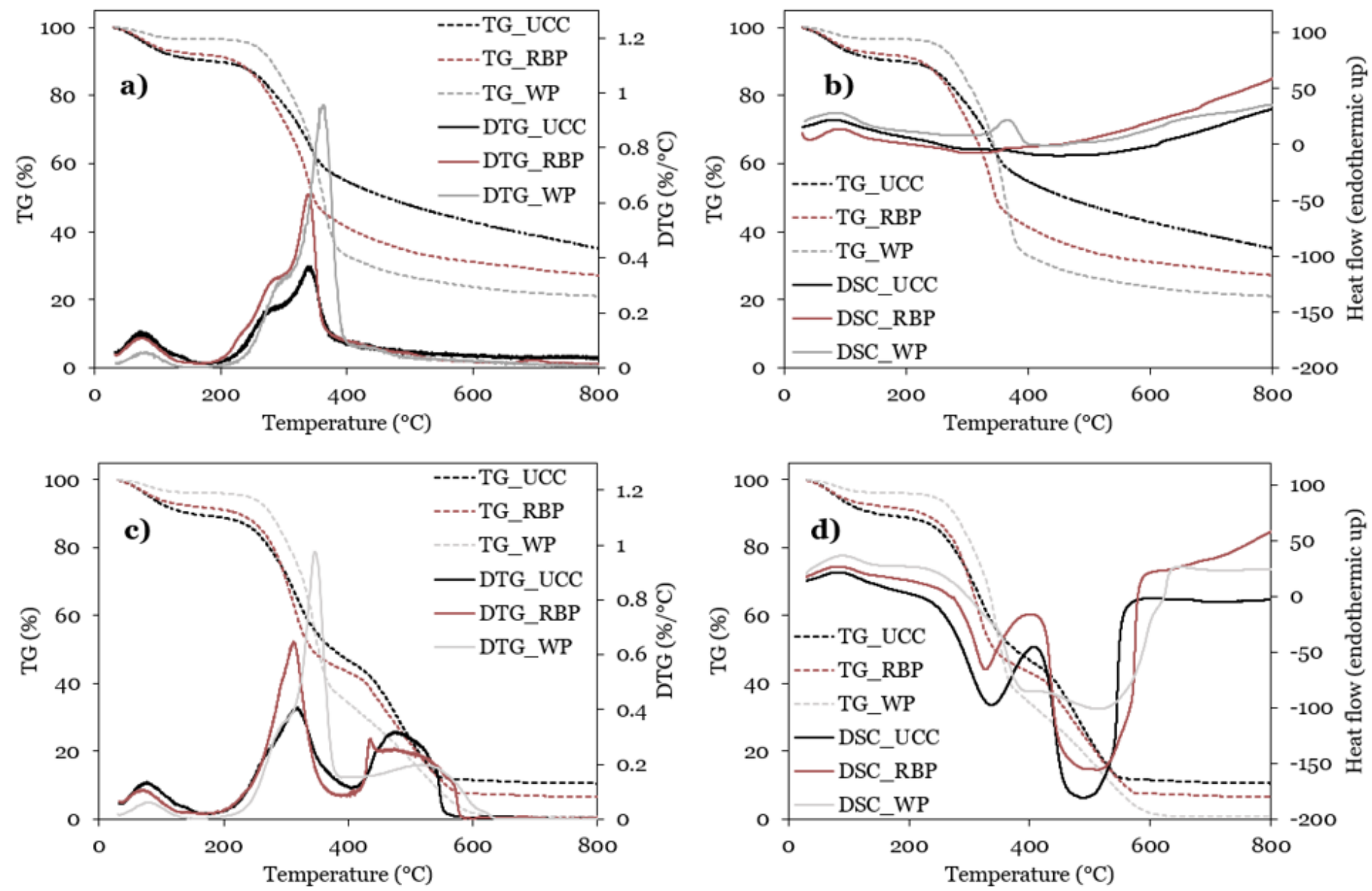

\section{Figure 3}

a) TG- DTG and, b) TG-DSC curves of raw materials under air, c) TG-DTG and, d) TG-DSC curves of raw material under $\mathrm{N} 2$. 


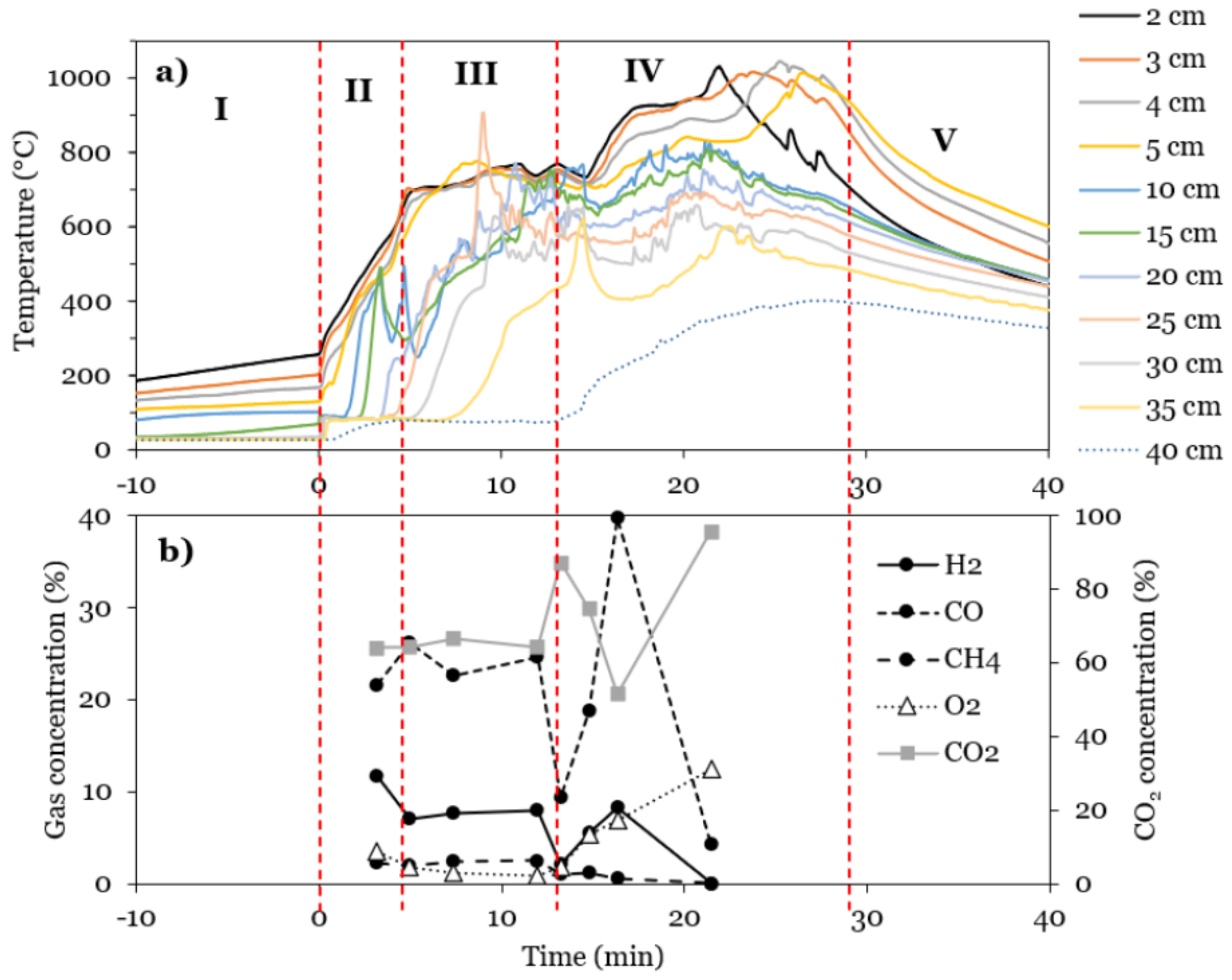

Figure 4

An example of the temperature and gas composition data collected from a smouldering experiment. a) Temperature history in relation to reactor height (distance from heater) and time since ignition $(t=0)$, and b) Evolution of gas composition versus time. 

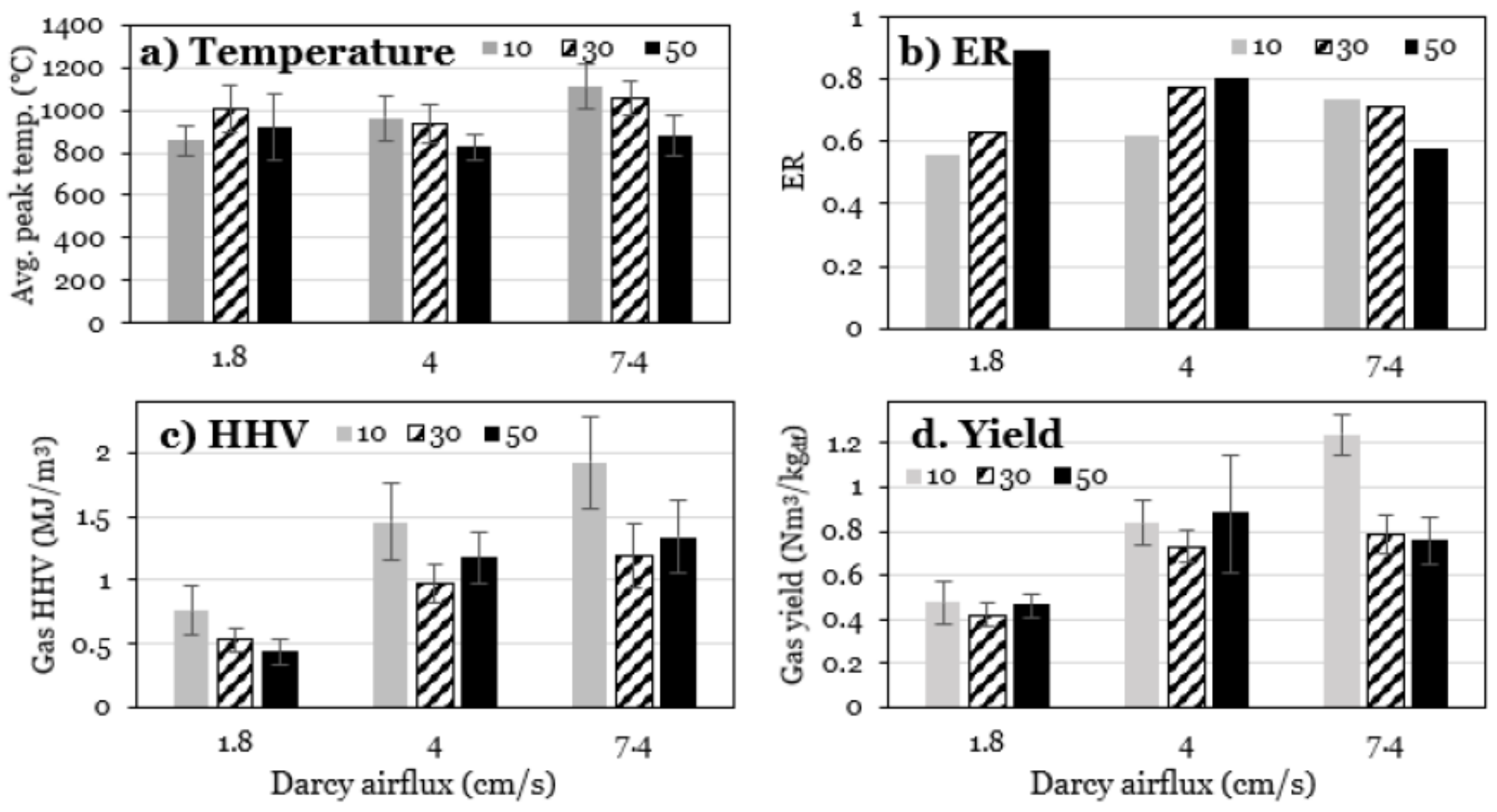

Figure 5

Smouldering of UCC: effect of moisture content and air flux on a) Average peak temperature, b) ER, c) HHV and, d) Yield.
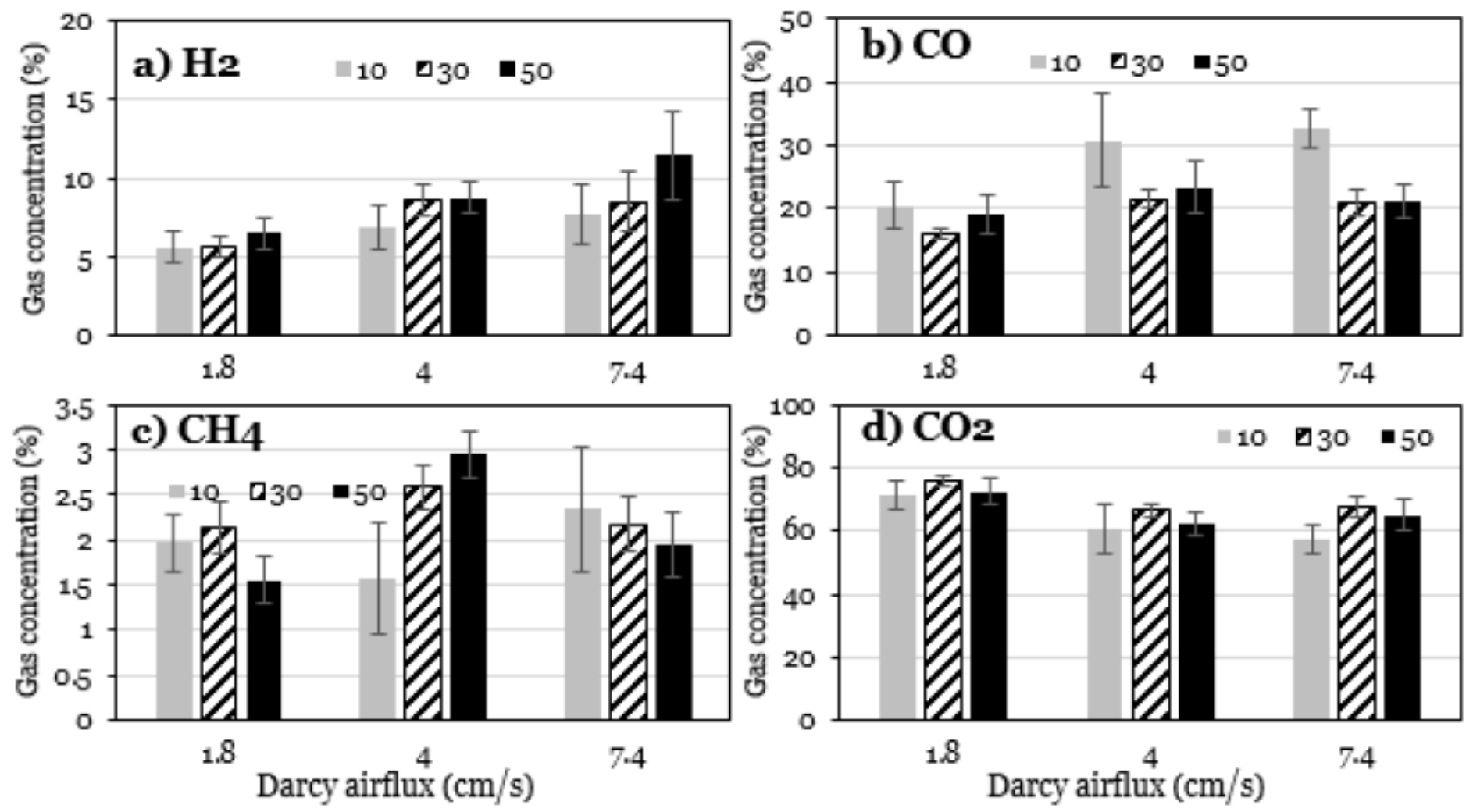
Figure 6

Smouldering of UCC: effect of moisture content and air flux on gas concentrations (N2 free) a) H2, b) CO, c) $\mathrm{CH} 4$, and d) $\mathrm{CO} 2$.
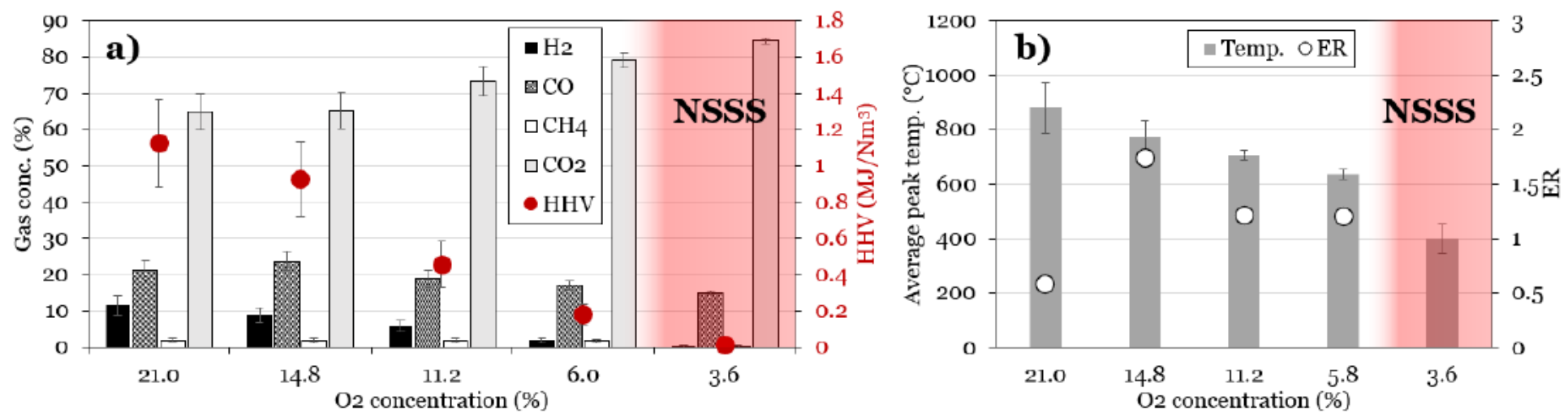

\section{Figure 7}

Effect of oxygen content on, a) Gas concentration (N2 free) and HHV and, b) Average peak temperature and ER. NSSS = non-self-sustaining smouldering. Experiments conducted on UCC at $50 \%$ moisture content and $7.4 \mathrm{~cm} / \mathrm{s}$ air flux.
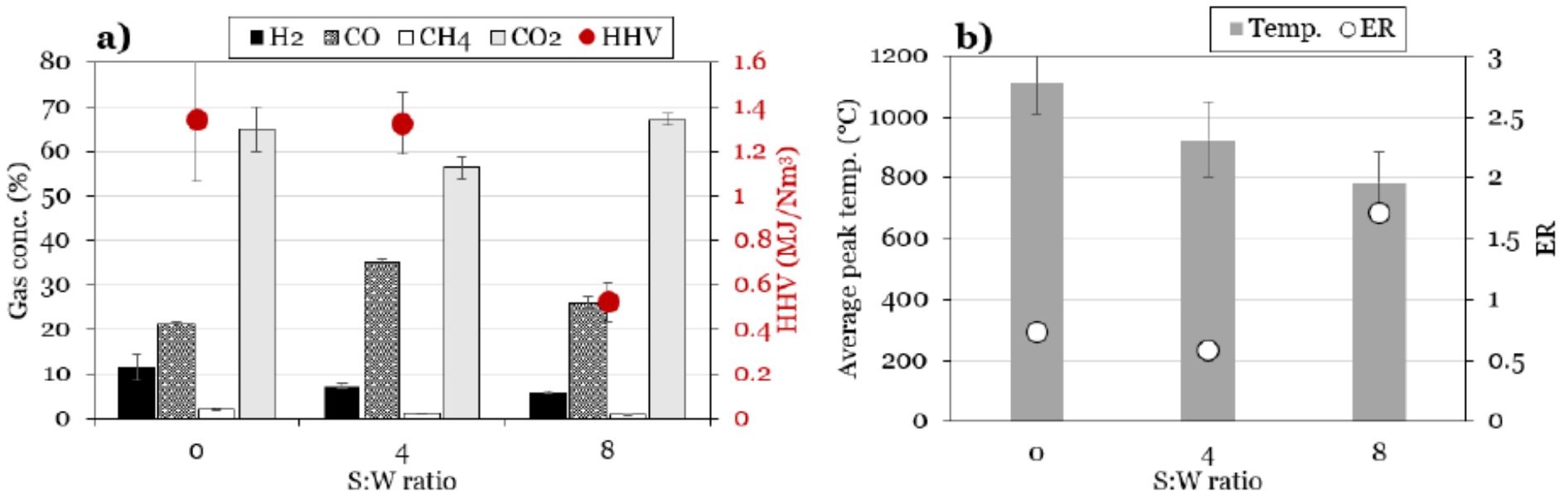

Figure 8

Effect of the addition of sand at 4 and $8 \mathrm{~S}: \mathrm{W}$ ratio (and 0 for comparison) on: a) gas concentration and $\mathrm{HHV}$ of gas products and b) Average peak temperature and ER. Experiments conducted at air flux of 7.4 $\mathrm{cm} / \mathrm{s}$ and feedstock at $50 \%$ moisture content. 

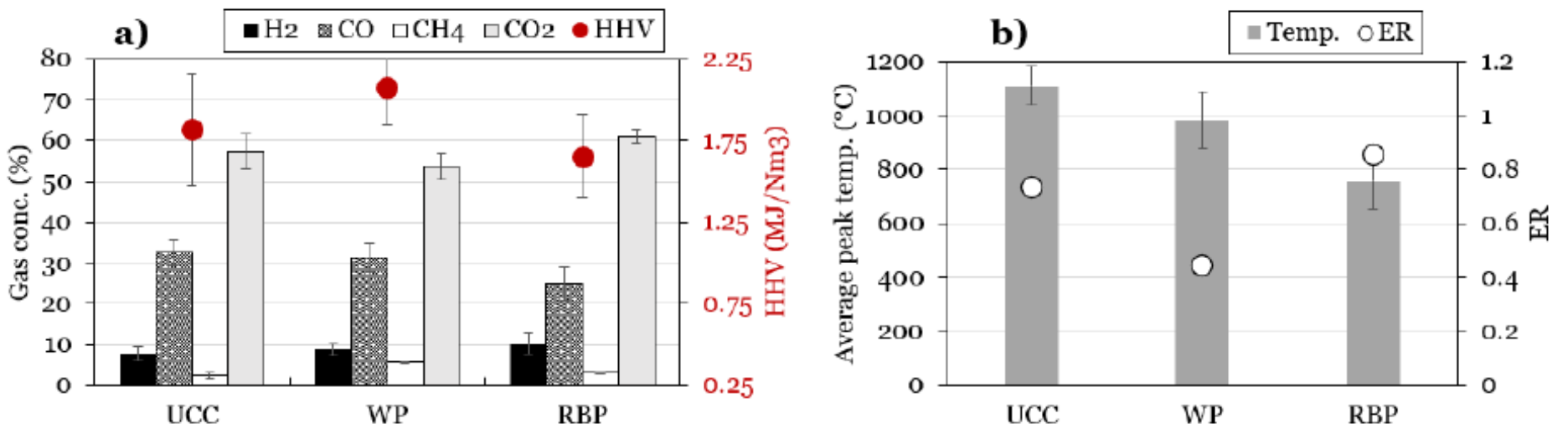

Figure 9

Effect of type of lignocellulosic material on a) gas concentration and HHV of product gas and b) average peak smouldering temperature and ER. Experiment conducted with air flux at $7.4 \mathrm{~cm} / \mathrm{s}$ and feedstocks at $10 \%$ moisture content. 